\title{
ANALISIS JUMLAH MUATAN LISTRIK SERTA ENERGI PADA KAPASITOR BERDASARKAN KONSTANTA DIELEKTRIK SUATU MATERIAL
}

\author{
Sinta Marito Siagian¹), Gede Wiratma Jaya²), Indah Nurhidayati ${ }^{3)}$ \\ 1)Program Studi Teknik Listrik, Jurusaan Teknik Elektro, Politeknik Negeri Medan \\ Jalan Almamater No.1 Kampus USU Medan, Kota Medan 20155 \\ ${ }^{2)}$ FIS Course, Jalan Loa Ipuh, Kec. Tenggarong, Kab. Kutai Kartanegara, Kalimantan Timur 75513 \\ ${ }^{3)}$ Program Studi Teknika, Politeknik Ilmu Pelayaran Semarang, Jl. Singosari Raya No.2A, Wonodri, Kec. Semarang Sel., \\ Kota Semarang, Jawa Tengah 50242 \\ Corrensponding author: Sinta Marito Siagian \\ Email : sintasiagian@polmed.ac.id
}

\section{Diterima 30 Maret 2021, Direvisi 06 Mei 2021, Disetujui 07 Mei 2021}

\begin{abstract}
ABSTRAK
Penelitian ini dilakukan untuk mengetahui nilai muatan listrik, nilai kapasitor yang dirangkai secara seri dan paralel kemudian nilai energi yang tersimpan pada kapasitor berdasarkan jenis-jenis material dengan konstanta dielektrik yang telah ditentukan. Metode yang dilakukan adalah mengkaji masingmasing nilai tersebut berdasarkan konstanta dielektrik dengan perhitungan matematis berbantuan Microsoft excel untuk menghasilkan grafiknya. Adapun tegangan yang digunakan pada metode ini adalah 20, 40, 60 dan 100 volt dan material yang dianalisis antara lain kaca, udara, mika, kertas dan polystiren. Analisis dilakukan menggunakan analisis kuantitatif yang memanfaatkan data berupa angka yang dipresentasikan melalui grafik. Ditemukan hasil perhitungan matematis bahwa kaca memiliki jumlah muatan yang lebih besar dibandingkan dengan material yang lainnya. pada saat dirangkaiakan secara seri dan paralel diperoleh bahwa jumlah muatan kapasitor yang dirangkaiakan secara paralel jauh lebih besar dibandingkan seri, energi yang tersimpan pada kapasitor yang dirangkaikan secara paralel juga memiliki nilai yang besar dari pada kapasitor yang dirangkai secara seri.
\end{abstract}

Kata kunci: kapasitor; konstata dielektrik; tegangan.

\begin{abstract}
This research aims are to analyze the value of the electric charge, the value of the capacitor connected in series and paralel then the energy value stored in the capacitor based on the types of materials with determined a dielectric constant. The method used to examine each of these values based on the dielectric constant with mathematical calculations assisted by Microsoft Excel to produce the graph. The voltages used on this methode are $20,40,60$, and 100 . The analysis using quantitative analysis that utilizes data in the form of numbers presented through graphs. It has been studied based on the physical formulation of the value of an electric charge against the dielectric constant of glass, air, mica, paper and polystyrene. It was found that the results of mathematical calculations show that glass has a greater amount of charge compared to other materials. When assembled in series and paralel, it is found that the amount of charge on the capacitor connected in paralel is much greater than in series, the energy stored in the capacitor connected in paralel also has a greater value than the capacitor connected in series.
\end{abstract}

Keywords: capasitor; dielectric constant; voltage.

\section{PENDAHULUAN}

Kapasitor merupakan suatu piranti elektronika yang dapat digunakan untuk menyimpan muatan listrik dan energi listrik (Nurmasyitah, 2017). Kapasitor memiliki muatan positif dan negatif yang menempel di masing-masing plat. Muatan yang terdapat di dalam kapasitor bersifat sementara, karena fungsi dari kapasitor berguna untuk membuat arus yang mengalir menjadi stabil. Didalam kapasitor terdapat pemisah antara kedua buah muatan yang berfungsi untuk menghindari kontak antara muatan yang tidak sejenis, pemisah kedua plat dikenal sebagai dielektrik. Dielektrik adalah suatu bahan yang memiliki daya hantar arus yang sangat kecil atau bahkan tidak ada. Bahan dielektrik tidak mempunyai elektron konduksi yang bebas bergerak di seluruh bahan oleh pengaruh medan listrik. Medan listrik tidak akan menyebabkan pergerakan muatan dalam bahan dielektrik. Sifat inilah yang menyebabkan bahan dielektrik itu merupakan isolator yang baik. Dalam bahan dielektrik semua elektron terikat dengan kuat pada intinya sehingga 
terbentuk suatu struktur regangan. Penelitian mengenai kapasitor dielektrik sebagaian besar dilakukan secara eksperimen dengan berbagai tujuan salah satunya mengetahui konstanta dielektriki berbagai jenis seperti bahan kertas, semen, dan lemak hewani (Supriyadi). Namun penelitian mengenai kajian teori belum banyak dilakukan sehingga menjadi peluang untuk melakukan analisa secara perhitungan matematis khususnya mengenai jumlah muatan listrik dan energi yang tersimpan pada kapasitor. Pada penelitian ini mengkaji pengaruh jumlah muatan listrik pada setiap kapasitor dielektrik beserta energi yang tersimpan pada kapasitor terhadap variasi sumber tegangan DC. Selain itu penelitian ini juga mengkaji susunan seri dan paralel kapasitor dielektrik untuk melihat jumlah muatan listrik dan energi yang dapat disimpan.

\section{METODE PENELITIAN}

Penelitian ini bersifat penelitian kajian teori dengan melakukan analisa kuantitatif berdasarkan jenis material dielektrik kapasitor terhadap muatan listrik dan energi kapasitor dengan berbagai variasi tegangan DC. Tegangan DC yang digunakan yaitu 20, 40, 60, 80 , dan 100 volt sebagai variabel bebas dan luas plat kapasitor yang digunakan sebesar 10 $\mathrm{cm}^{2}$ dan jarak antar plat kapasitor sebesar 10 $\mathrm{cm}$ sebagai variabel terikat. Adapun gambaran skematik kapasitor dapat dilihat pada Gambar 1.

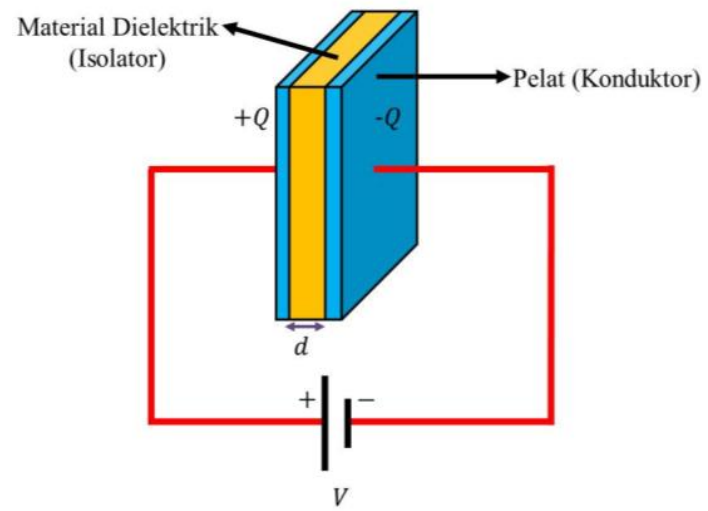

Gambar 1 Kapasitor dengan material dielektrik

Kapasitor dengan material dielektrik (Gambar 1) memiliki nilai kapasitansi kapasitor (C) yang berbeda dengan kapasitor tanpa material dielektrik. Adapun persamaan nilai kapasitansi kapasitor dengan material dielektrik dapat ditulis dengan persamaan 1

$$
C=K \varepsilon_{O} \frac{A}{d}
$$

dengan $C$ adalah kapasitansi kapasitor $(\mathrm{F}), K$ adalah konstanta dielektrik material yang didisipkan pada kapasitor, $\varepsilon_{O}$ adalah permitivitas ruang hampa dengan nilai $8,85 \times$
$10^{-12} \mathrm{~F} / \mathrm{m}, A$ adalah luas penampang kapasitor $\left(\mathrm{m}^{2}\right)$, dan $d$ adalah jarak antar plat kapasitor (m). Untuk besarnya muatan listrik yang dapat disimpan oleh kapasitor menggunakan material dielektrik dapat ditulis dalam bentuk persamaan 2

$$
Q=\left(K \varepsilon_{O} \frac{A}{d}\right) V
$$

dengan $Q$ adalah jumlah muatan listrik (C), dan $V$ tegangan DC (V) (Abdullah, 2017). Adapun jenis material dielektrik kapasitor yang akan digunakan yaitu udara, kaca, mika, kertas, dan polystyrene dengan nilai konstanta dielektrik yang dapat dilihat pada Tabel 1 .

Tabel 1. Nilai konstanta dielektrik masingmasing material (Tipler \& Soegijono, 2001)

\begin{tabular}{cc}
\hline $\begin{array}{c}\text { Material } \\
\text { Dielektrik }\end{array}$ & $\begin{array}{c}\text { Nilai Konstanta } \\
\text { Dielektrik }\end{array}$ \\
\hline Udara & 1,00 \\
Kaca & 5,60 \\
Mika & 5,40 \\
Kertas & 3,70 \\
Polystirene & 2,55 \\
\hline
\end{tabular}

Kapasitor dengan material dielektrik yang berbeda disusun secara seri (Gambar 2a) dan disusun secara paralel (Gambar 2b) untuk mencari seberapa besar kapasitansi kapasitor rangkaian seri dan paralel. Adapun persamaan kapasitor rangkaian seri dan paralel dapat dituliskan sebagai berikut berdasarkan persamaan 3 dan 4

$$
\begin{gathered}
\frac{1}{C_{\text {seri }}}=\sum_{i=1}^{N} \frac{1}{C_{i}} \\
C_{\text {paralel }}=\sum_{i=1}^{N} C_{i}
\end{gathered}
$$

dengan $C_{\text {seri }}$ adalah kapasitansi kapasitor rangkaian seri $(\mathrm{F}), C_{\text {paralel }}$ adalah kapasitansi kapasitor rangkaian paralel $(\mathrm{F})$, dan $C_{i}$ adalah suatu fungsi dengan variabel $i$. Kemudian untuk mencari muatan total yang dapat disimpan pada kapasitor susunan seri dan paralel dapat ditulis dalam persamaan 5 dan 6 berikut

$$
\begin{aligned}
Q_{\text {seri }} & =C_{\text {seri }} V \\
Q_{\text {paralel }} & =C_{\text {paralel }} V
\end{aligned}
$$



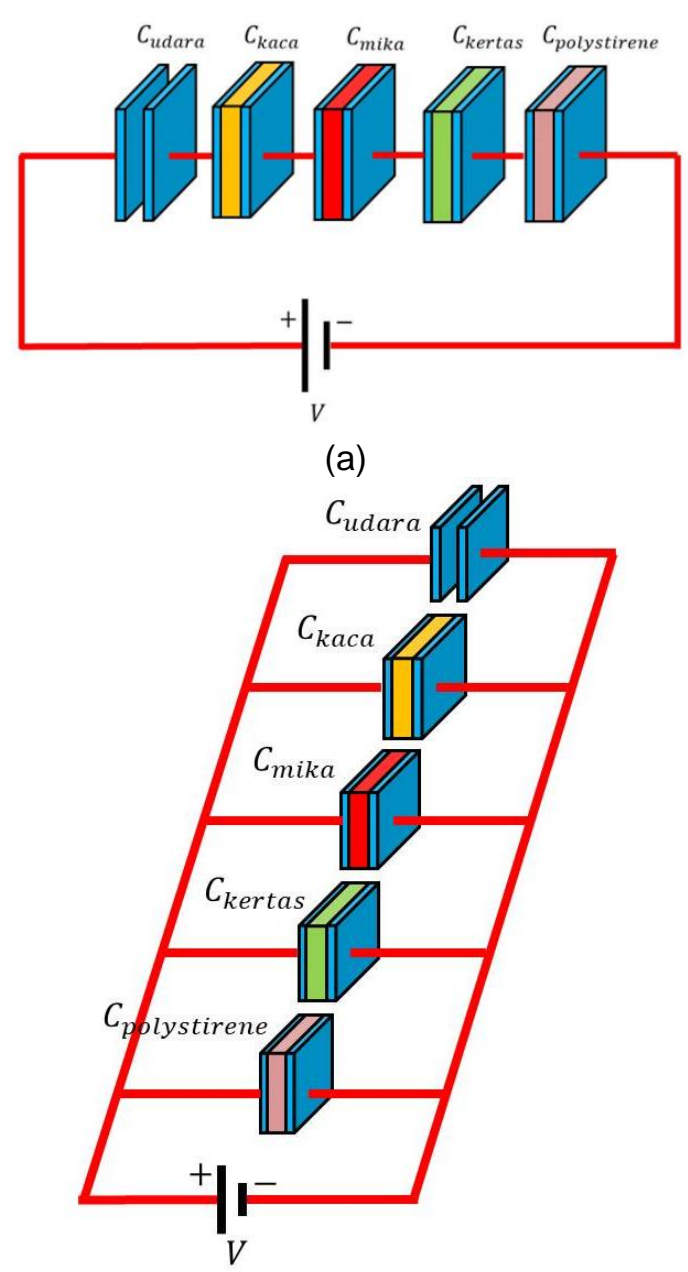

(b)

Gambar 2. Rangkaian kapasitor yang disusun seri (a) dan (b) disusun secara paralel

Energi yang tersimpan pada kapasitor untuk masing-masing dielektrik maupun disusun secara seri dan paralel secara umum dapat dituliskan dalam bentuk persamaan sebagai berikut:

$$
W=\frac{1}{2} C V^{2}
$$

dengan $W$ adalah energi yang tersimpan pada kapasitor (J), $C$ adalah kapasitansi kapasitor $(\mathrm{F})$, dan $V$ adalah tegangan (beda potensial) $(\mathrm{V})$ (Yakin, 2019)

\section{HASIL DAN PEMBAHASAN}

Kapasitor pada dasarnya akan menyimpan energi dalam bentuk medan jika dihubungkan pada sebuah sumber tegangan. Besarnya energi listrik yang tersimpan oleh kapasitor sama dengan usaha yang diperlukan untuk memindahkan muatan listrik dari sumber tegangan tersebut ke dalam kapasitor. Jika suatu kapasitor dengan kapasitansi (C) dihubungkan dengan suatu sumber tegangan DC $(V)$ maka setelah beberapa waktu kapasitor akan terisi oleh muatan. Data grafik yang berasal dari penurunan persamaan hasil kali antara tegangan $\mathrm{DC}(V)$ dan nilai kapasitas kapasitor $(C)$ menghasilkan hubungan antara jumlah muatan listrik $(Q)$ terhadap variasi tegangan $\mathrm{DC}(V)$ untuk masing-masing material dielektrik yang dapat dilihat pada Gambar 3. Berdasarkan data grafik menunjukkan kapasitor dengan dielektrik material kaca memiliki jumlah muatan yang lebih besar, lalu disusul dengan dielektrik dari material mika, kertas, polystyrene, dan udara.

Dari grafik pada Gambar 3 dapat dikaji bahwa semakin besar tegangan yang diberikan pada suatu kapasitor, maka makin besar nilai muatan listrik yang tersimpan pada plat kapasitor tersebut, dan sebaliknya jika tegangan semakin kecil maka muatan listrik yang tersimpan akan semakin kecil.

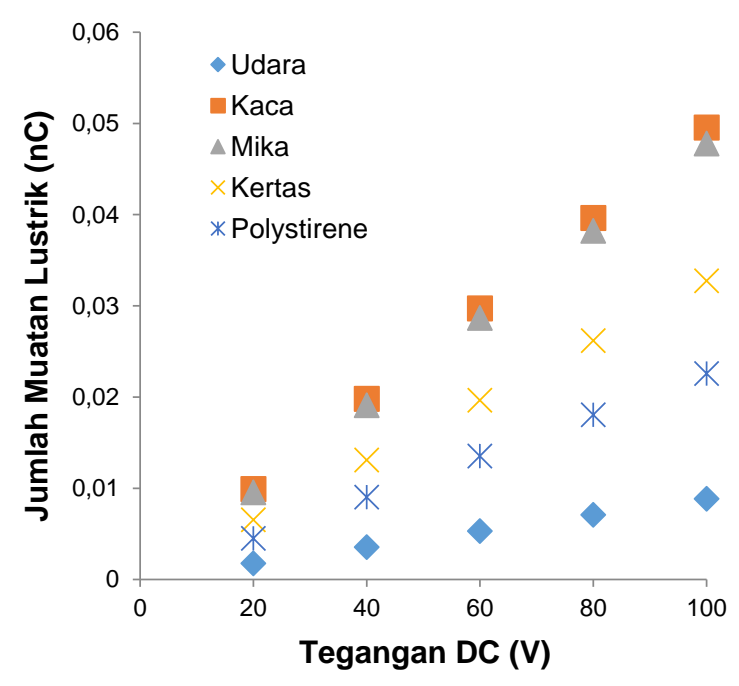

Gambar 3. Grafik muatan listrik terhadap tegangan DC untuk setiap material dielektrik

Suatu kapasitor yang memiliki muatan dapat memberikan arus Istrik pada suatu komponen dalam rangkaian listrik. Pemberian arus ini sama hal nya dengan transfer energi atau pemberian energi, jika ditinjau prinsip ini sama dengan baterai dan aki yang dapat menghasilkan arus listrik jika terhubung pada suatu beban terhadap suatu rangkaian. Oleh sebab itu suatu kapasitor yang bermuatan dapat menyimpan sejumlah energi. Sama halnya dengan material kaca yang memiliki jumlah muatan terbesar, tentunya dapat menyimpan energi.

Kapasitor yang disusun secara seri dan paralel memiliki jumlah muatan listrik yang berbeda. Menggunakan persamaan yag telah ditentukan secara fisika pada kapasitor menghasilkan nilai muatan listrik $(Q)$ terhadap variasi tegangan DC $(V)$ yang dapat dilihat pada Gambar 4. Hasil ini menunjukkan kapasitor yang disusun secara paralel menghasilkan jumlah muatan 
listrik yang jauh lebih besar dibandingkan rangkaian seri. Namun jumlah muatan listrik pada rangkaian seri jauh lebih kecil dibandingkan kapasitor dengan dielektrik dari dari material udara.

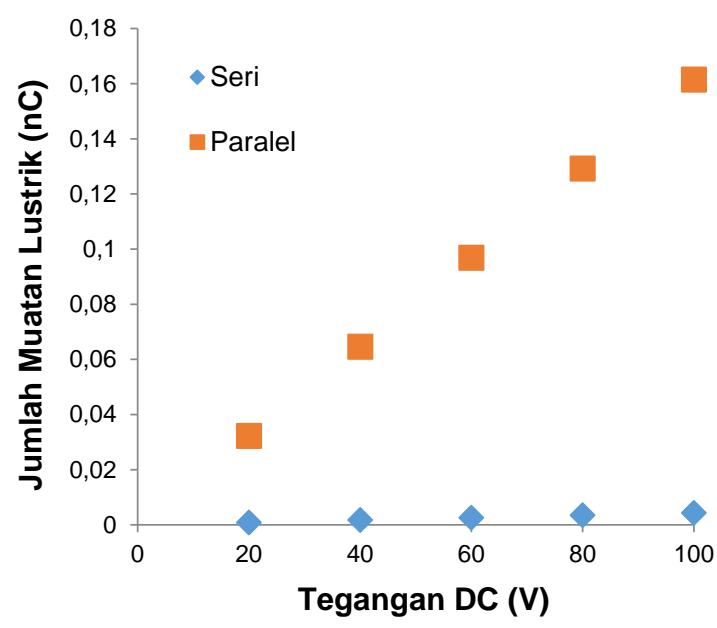

Gambar 4. Grafik muatan listrik terhadap tegangan DC untuk susunan kapasitor seri dan paralel

Tinjauan selanjutnya adalah energi kapasior, dengan kombinasi persamaan antara kapasitor dengan kuadrat tegangan diperoleh hubungan energi kapasitor $(W)$ terhadap variasi tegangan DC $(V)$ yang dapat dilihat pada Gambar 5 . Ketika kapasitor mengisi daya dari catu daya yang terhubung dengannya, makan akan menghasilakn medan elektrostatis yang berfungsi untuk menyimpan energi dalam kapasitor. Jumlah energi dalam satuan joule yang disimpan dalam medan elektrostatis ini sama dengan energi yang diberikan oleh pasokan tegangan untuk mempertahankan muatan pada plat kapasitor. Berdasarkan perhitungan matematis dengan rumusan yang telah ditetapkan, diperoleh hasil energi yang tersimpan pada kapasitor.

Hasil tersebut menunjukkan energi kapasitor dari rangkaian paralel memiliki nilai energi kapasitor yang jauh lebih besar. Sedangkan energi kapasitor dari rangkaian seri memiliki nilai energi yang sangat kecil. Untuk perbandingan antar material dielektrik, dielektrik dengan material kaca memiliki energi kapasitor yang lebih tinggi dibandingkan material dieletrik lainnya. Disusul dengan material dielektrik dari material mika, kertas, polystyrene, dan udara.

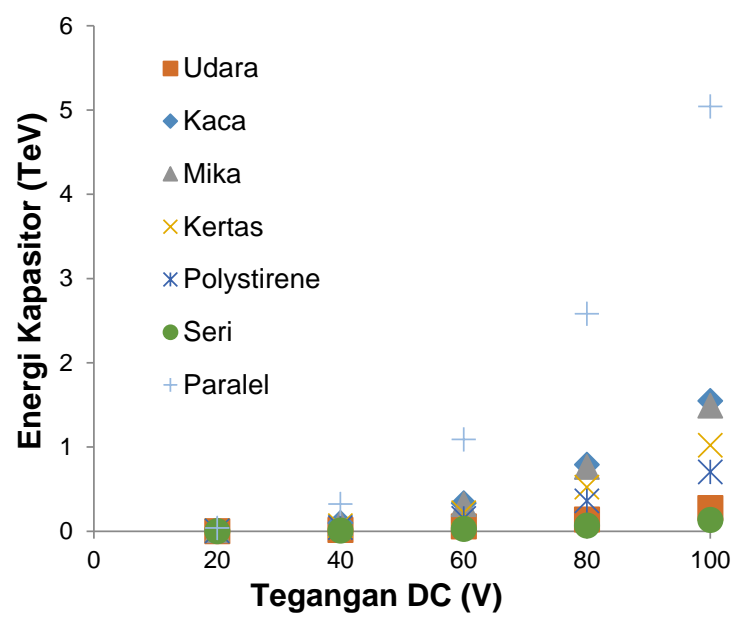

Gambar 5. Grafik energi kapasitor terhadap tegangan DC untuk setiap material kapasitor, susunan seri, dan paralel

\section{SIMPULAN DAN SARAN}

Berdasarkan hasil kajian tentang dielektrik pada material kaca, kertas, mika, polystiren dan udara, dapat disimpulkan bahwa jumlah muatan listrik yang terbesar berada pada material kaca sebesar 5,31 $\times 10^{-10} \mathrm{C}$ dengan konstanta dielektrik sebesar 5,6. Energi tersimpan pada kapasitor yang dirangkaikan secara paralel lebih tinggi pada tegangan DC 100 volt dan cenderung linear dibandingkan dengan kapasitor yang dirangkaikan seri.

\section{UCAPAN TERIMAKASIH}

Terimakasih kepada seluruh pihak yang tidak dapat disebutkan satu persatu karena telah membantu penulisan jurnal, sehingga jurnal ini dapat terselesaikan dengan baik .

\section{DAFTAR RUJUKAN}

Abdullah, M. (2017). Fisika Dasar II. Bandung. Institut Teknologi Bandung.

Basorudin, B., dan Irawan, A. 2017. Aplikasi Perhitungan Kapasitor Surface Mount Device. Riau Journal Of Computer Science 3, pp. 49-62.

Cahyono, B.E., Misto, M., dan Arviah, H.R. 2017. Analisa Kualitas Semen Melalui Pengukuran Konstanta Dielektrik dan Resitivitas. Jurnal Rekayasa Energi Manufaktur 2, pp. 57-61.

Nurmasyitah, N. (2017). PENENTUAN KONSTANTA DIELEKTRIK AKRILIK. Jurnal Jeumpa, 4(2), 50-54.

Rimafatin, N, Cahyono, B.E., dan Misto, M. 2019. Analisis Hubungan Suhu dan Frekuensi Terhadap Sifat Listrik Hewani. Jurnal Fisika Flux 16, pp. 7883. 
Supriyadi, S. Konstanta Dielektrik Bahan Kertas Karton Pada Keping Sejajar. Jurnal Fisika Unnes, 4(2), 79886.

Tipler, P. A., \& Soegijono, B. (2001). Fisika: untuk sains dan teknik, jilid 2.

Yakin, K. (2019). Teori dasar listrik dan rangkaiannya. In: Literasi Nusantara. 